\title{
Correlation Study Between PMT and SPT Results of Artificially Filled Area
}

\author{
Özgür Yıldız \\ Malatya Turgut Özal University, Civil Engineering Department, Malatya, Turkey, (ORCID: 0000-0002-3684-3750), \\ ozgur.yildiz@,ozal.edu.tr
}

(International Conference on Design, Research and Development (RDCONF) 2021 - 15-18 December 2021)

(DOI: 10.31590/ejosat.1039196)

\begin{abstract}
ATIF/REFERENCE: Yildiz, Ö. (2021). Correlation Study Between PMT and SPT Results of Artificially Filled Area. European Journal of Science and Technology, (32), 126-134.

Abstract

The non-linear nature of the soils can cause the parameters to change significantly even in a limited area. In site investigation studies, the sampling frequency is important in determining soil properties with sufficient accuracy and in developing an idealized soil profile in which the engineering design will be made. Statistical methods are used in cases where field studies cannot be done adequately due to technical limitations, unsuitability of the study area and cost problems. These methods usually provide important information about the soil at the preliminary design stage. While statistical methods are used by researchers and practitioners to obtain soil parameters, no study has been found in the literature on the use of these methods in artificially filled areas. In this study, the soil parameters of the filled area created in the Yenikap1, İstanbul with an area of $715.000 \mathrm{~m}^{2}$ were examined. In this context, empirical correlations have been developed between the parameters obtained by the geotechnical tests carried out and the relationships between the soil parameters have been revealed. The data obtained from pressuremeter and standart penetration tests were used in correlations. The developed correlations were compared with the empirical correlations developed for natural soils and important findings were obtained.
\end{abstract}

Anahtar Kelimeler: Standard penetration test, Pressuremeter test, Correlation, Bearing capacity

\section{Yapay Dolgu Alanına ait PMT ve SPT Sonuçları Arasında Korelasyon Çalışması}

$\ddot{\mathbf{O} z}$

Zeminlerin doğrusal olmayan yapısı, sınırlı bir alanda bile parametrelerin önemli ölçüde değişmesine neden olabilmektedir. Zemin etüt çalışmalarında numune alma sıklığı, zemin özelliklerinin yeterli doğrulukla belirlenmesinde ve mühendislik tasarımının yapılacağ ortamın idealize zemin profilinin oluşturulmasında önemlidir. Teknik yetersizlikler, çalışma alanının uygun olmaması ve maliyet gibi gerekçelerle saha araştırmalarının yeterince yapılamadığı durumlarda istatistiksel yöntemlerden istifade edilmektedir. Bu yöntemler genellikle ön tasarım aşamasında zemin hakkında önemli bilgiler vermektedir. İstatistiksel yöntemler, araştırmacılar ve uygulayıcılar tarafından zemin parametrelerinin elde edilmesi için kullanılırken, literatürde bu yöntemlerin yapay dolgu alanlarındaki kullanımına ilişkin herhangi bir çalışmaya rastlanmamıştır. Bu çalışmada $715.000 \mathrm{~m}^{2}$ genişliğindeki Yenikapı, İstanbul' da oluşturulan dolgu alanının zemin parametreleri incelenmiştir. Bu kapsamda dolgu alanında gerçekleştirilen geoteknik testler ile elde edilen parametreler arasında ampirik korelasyonlar geliştirilmiş ve zemin parametreleri arasındaki ilişkiler ortaya konmuştur. Bu çalışmada özellikle korelasyonlarda ve taşıma kapasitesinin hesaplanmasında pressiyometre ve satndart penetrasyon testlerinden elde edilen veriler kullanılmıştır. Geliştirilen korelasyonlar, doğal zeminler için geliştirilen ampirik korelasyonlar ile karşıllaştırılmış ve önemli bulgular elde edilmiştir.

Keywords: Standart penetrasyon testi, Pressiyometre testi, Korelasyon, Taşıma gücü

\footnotetext{
* Corresponding Author: ozgur.yildiz@,ozal.edu.tr 


\section{Introduction}

Yenikap1 is located on the coast of the Marmara Sea within the borders of the Fatih district of Istanbul. At the intersection of Kennedy Street and Mustafa Kemal Avenue, it is adjacent to Samatya to the west, Kumkap1 to the east, and Aksaray to the north. Within the scope of the Yenikap1 Square Project developed by Istanbul Metropolitan Municipality, 518 thousand $\mathrm{m}^{2}$ of the total project area of 715 thousand $\mathrm{m}^{2}$ was created by filling the seabed. In the context of the Yenikap1 Square project a meeting, a concert, and an event area with a capacity of 1.250 .000 people were constructed. An open car park with a capacity of 3.000 vehicles and green space of $450.000 \mathrm{~m}^{2}$ was built in the project. A stage in the square, huts for health, administrative and security units, cafe, buffet, restaurant and exhibition areas, wooden piers, and handicapped lodges were built in the square. It is also planned to establish an advanced biological treatment plant with a capacity of 1.350.00 tons/day in the filling area. The construction of the project, which started in April 2013, was completed in February 2014. In addition to all of these features, Yenikap1 station, which provides a transit pass to the Anatolian side and is the hub for transportation to different parts of the European side, hosts a suburban railway, metro line, submarine railway connection (Marmaray) between Europe and Asia. The entrance of the Eurasia Submarine Motorway Tunnel on the European side is also close to the Yenikap1 coast (Figure 1).

The Yenikapı Square Project has controversially brought up the design of the coastal and filling areas and the intervention to the coasts. In Istanbul, while the natural coastal borders were preserved until the 1950s, the city tended to grow towards the sea due to the lack of urban space which is an expected consequence of rapid urbanization. Thus, the coasts, which can be defined as natural borders, have begun to be reorganized with filling areas. The first seabed filling operations in Istanbul are vehicle road works on the shores of the Golden Horn and bypassing the historical peninsula. Later, factories and houses were built intensively on this filling area. After the 1980s, these works gained momentum and over time they continued to grow in different parts of the city. Especially after the 2000s, with the effect of globalization, Istanbul has become one of the centers of attraction for global capital, and the Galataport project, Haydarpaşa Train Station Project, Kartal and Küçükçekmece Urban Transformation Projects have also been the reflections of this trend on the coast [1].

While the use of coastal areas, which came to the fore with the Yenikapi Square Project, is evaluated under the heading of urbanization, the fact that there are few similar engineering designs has been a motivation of this study. The low strength and high compressibility potential of embankments make them worth of examining. This situation makes it even more difficult to predict the problems of filling layer-foundation interaction problems [3]. In cases where the foundation soil is more rigid than the embankment, the slip surface usually remains in the embankment. However, in cases where the foundation soil is of lower strength, collapses occur within the foundation soil. In both cases, two design criteria; stability and bearing capacity should be considered. Even under very small loads, collapses may occur in the first stages of fillings on very soft soils. The thickness of the filling layer, which must be a point to take into consideration in order to prevent this failure, can be obtained so thin that cannot be applied in practice, and it is not carried out with sufficient care during the construction. It is normally applied without any calculation in the first stages of embankments built especially in very soft soil environments in the seabed or river beds. Accordingly, different filling models have been proposed to prevent this problem especially for seabed soils [4].

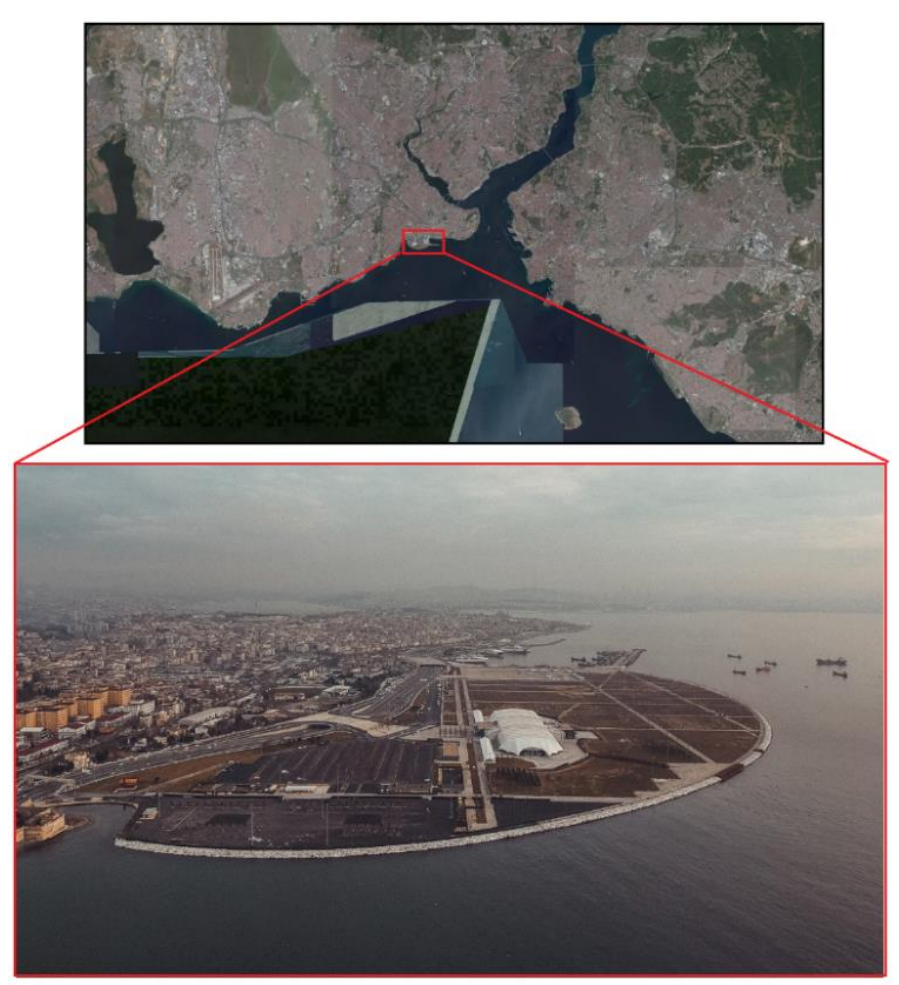

Figure 1. Location map of the Yenikap1 Square [2]

The fact that field tests require a costly and labor-intensive study, and field conditions are unsuitable for testing in some cases offers an option to obtain the parameters to be used in the preliminary design of geotechnical structures indirectly. Empirical correlations developed between parameters obtained from site investigations or laboratory tests are very useful for making a practical engineering prediction of soil parameters. It is possible to derive many design parameters using appropriate empirical correlations, thus limiting our reliance on these soil tests [5]. The correlations between SPT-N and $\mathrm{E}_{\mathrm{M}}$ are developed by many researchers. Chiang and Ho [6] formulated the relationship between SPT-N and pressuremeter testing parameters for weathered formations. Ohya [4] developed similar correlations for clayey soils. Briaud and Jordan [8] used pressuremeter test results to calculate the bearing capacity and settlement of various shapes of shallow foundations using a set of charts. Briaud [9] developed a relationship between SPT and pressuremeter test results of sand and clays. Yagiz et al. [10], for a particular region, obtained quite high correlation coefficients between SPT-N and pressuremeter test parameters $\mathrm{E}_{\mathrm{PMT}}$ and $\mathrm{P}_{\mathrm{L}}$. Bozbey and Toğrol [11] used data of Istanbul soils and developed equations. Yildiz [12] obtained similar correlation coefficients between SPT-N and EPMT, $_{\mathrm{L}}$ of Istanbul soils. Cheshomi and Ghodrati [13] developed correlations for silty sand and silty clays. Kayabasi [14] proposed empirical equations for Mersin city. Due to the ease of accessing local soil test data, similar studies based on the correlation of test data were also conducted for different cities by researchers [15$18]$.

Before the design stage of engineering structures, while the parametric equations were developed by the researchers for 
natural soils and the embankments built on these areas, a particular study on the engineering properties of a filling area was not found in the literature. In this study, correlations between the soil parameters obtained by the site investigation studies carried out in the Yenikapı Filling Area were developed. They were compared with the results obtained from the studies based on the same approach in the literature. The bearing capacity of the soil was calculated by using the pressuremeter test data of the application area. Obtained soil parameters and developed correlations are presented graphically and the findings were compared with those of natural soil environments

\section{Methodology}

\subsection{General Geology}

The regional bedrock consists of the Paleozoic (Carboniferous) aged Trakya Formation. Greywacke and clayey schists, which are the main lithological units of this formation, were formed from coarse grain soils by a mud subsidy deposited by turbiditic currents under deep marine conditions. As seen on both sides of Istanbul and the entire Kocaeli side, the region was deformed with tectonic movements at the end of the Carboniferous. This situation, which continued until the beginning of the Middle Eocene, changed after the Middle Eocene and the region became a marine environment again. Due to the fact that the terrestrial morphological structure in this period was not very strong and also due to the current climate characteristics, the marine environment continued to develop at shallow depths and carbonates were deposited in this environment.

As a result of the geological events summarized, a new terrestrialization period has been begun in the region and the Oligocene aged Gürpınar Formation, which is the oldest lithostratigraphic unit of the region, has developed with the fragments that emerged under the conditions of meandering rivers that are active from time to time. On the Gürpınar clays, the Miocene aged Çukurçeşme Formation, which consists mainly of gravely sand and sandy gravel levels, is located. The clay-sandsilt levels of the Miocene aged Çekmece Formation of Güngören Member are also above this unit. The Bakırköy Limestone unit, which consists of shelled limestones and chalky marls is at the top. The whole or part of the regressive sediments represented by flood plain, lake and swamp deposits in the Trakya basin is defined as the Danişmen Formation, which consists of sandstone, conglomerate and siltstone interbedded, claystone and shales and includes tuff-tuffite and coal (lignite) interfaces. The Çekmece Series, which is widespread in the western part of the European side of Istanbul, between the coasts of the Marmara Sea and the Black Sea coast, consists of two members, the Çekmece Formation, which also includes red-brown pebble-sand deposits, from bottom to top; Güngören Member and Bakırköy Member. The Generalized Geological Map of the region and stratigraphic section is given in Figures 2 and 3, respectively.

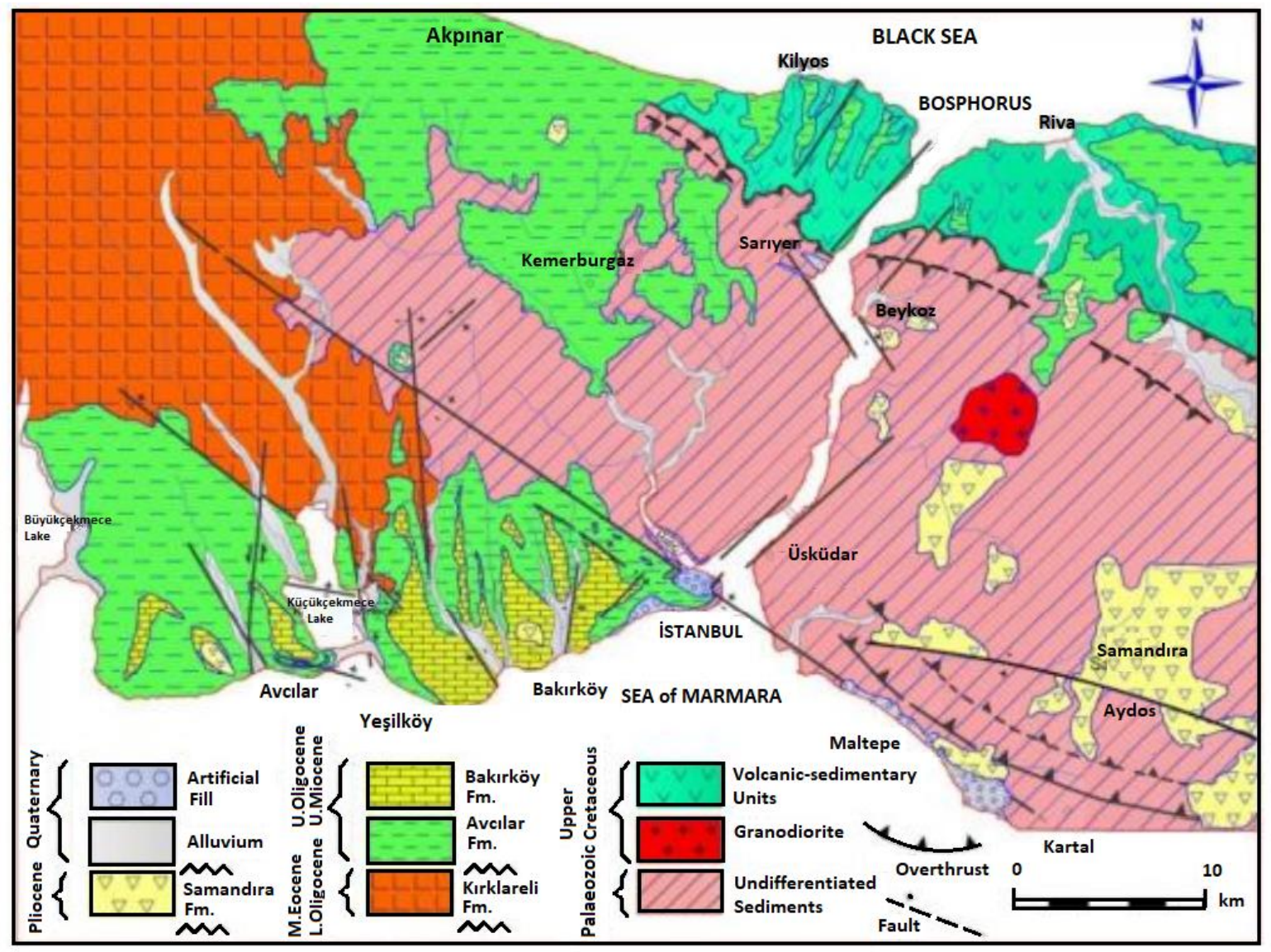

Figure 2. General geological map of Istanbul and Its surrounding area [5]

\subsection{Site investigation studies}

In order to determine the soil parameters of the geological structure in the study area, 6 borehole drilling with a total depth of 219 meters were made. Drilling number 7, which was planned to be made in the early stages, was canceled due to operational reasons. With the SMK-400 Full Hydraulic system drilling machine, a $76 \mathrm{~mm}$ single tube core barrel in the drillings was used. Boreholes in the filling units are protected with a $100 \mathrm{~mm}$ diameter casing pipe. Disturbed and undisturbed soil samples 


\section{Avrupa Bilim ve Teknoloji Dergisi}

were taken from the boreholes. These samples were selected to represent the site accurately, and laboratory tests were carried out. Standard Penetration Tests (SPT) were performed with an average of $1.5 \mathrm{~m}$ intervals. The site plan of the drillings carried out in the study area is given in Figure 4. As it is known, the Pressuremeter test is an in-situ test in which the stress-strain response of the soil is determined. The test is performed by inflating an expandable cylindrical probe in a pre-drilled well and measuring the pressure and volume changes in the probe. As a result of the test, Limit Pressure, $\mathrm{P}_{\mathrm{L}}$ and Menard Pressuremeter Modulus, $\mathrm{E}_{\mathrm{m}}$ measurements of the relevant soil depth were taken. Within the scope of the study, 25 pressuremeter tests were carried out at different depths in 5 boreholes. Field studies were performed in accordance with TS 5744 (In-situ Measurement of Foundation Soil Properties in Civil Engineering) specification.

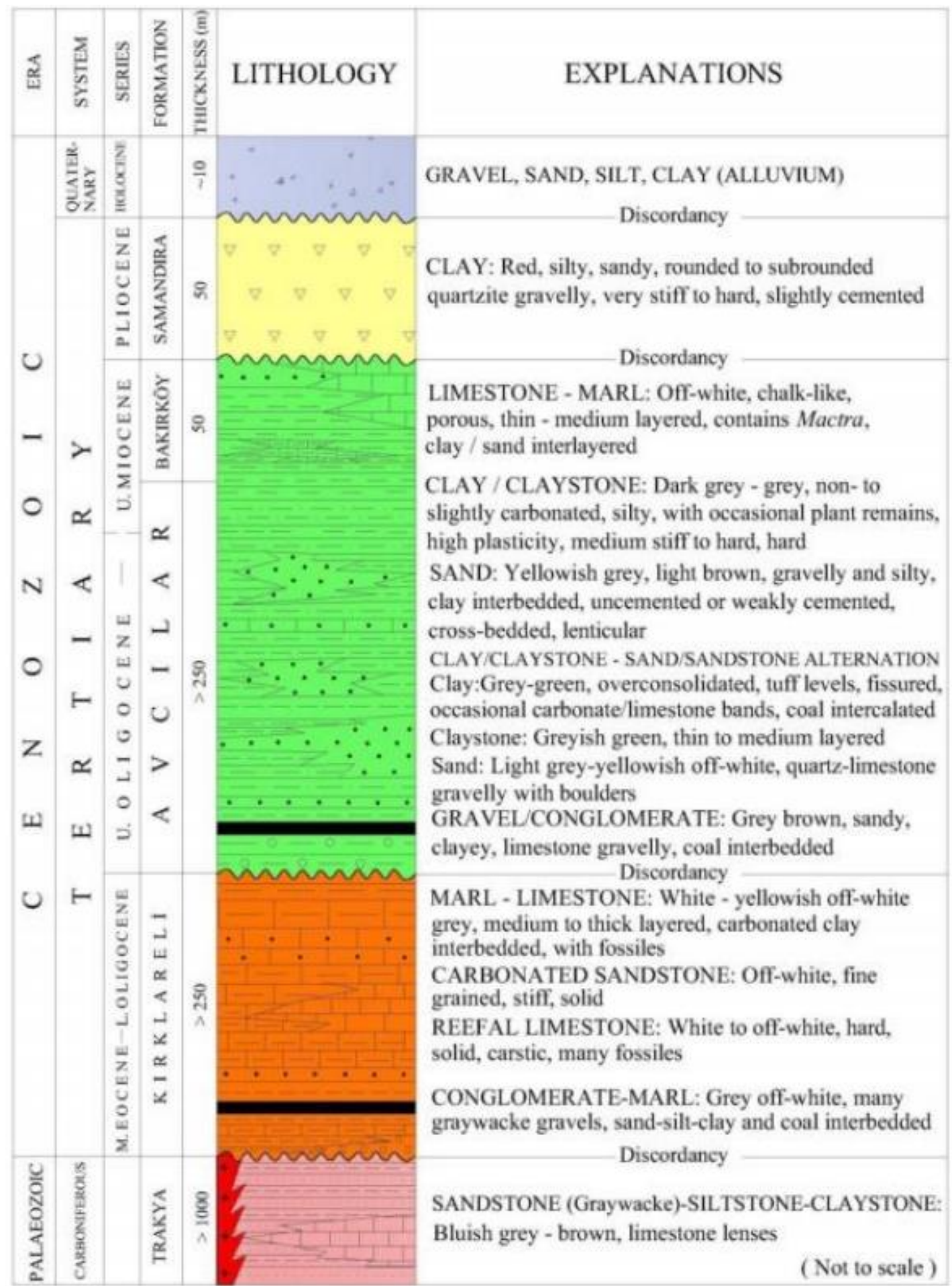

Figure 3. The aspect of updated stratigraphy and typically observed deposits [5]

\section{Results and Discussion}




\section{European Journal of Science and Technology}

The artificial fill layer is in the form of green-light brown clay-sand intercalation, which is included in the Güngören Member of the Çekmece Formation, and gray-colored silty hard clay units within the Gürpınar Member of the Danişmen Formation are encountered in the research area. Detailed lithological descriptions of these formations are given in the previous section. Groundwater level was measured through boreholes drilled in the study area, and the groundwater was determined at a depth of 3.10 meters in the $\mathrm{BH} 1$ well, 3.75 meters in the $\mathrm{BH} 2$ well, 4.05 meters in the $\mathrm{BH} 3$ well, 3.40 meters in the BH4 well, 5.20 meters in the BH5 well and 4.00 meters in the BH6 well. A summary of the measured Groundwater Table (GWT) levels and the recorded dates are given in Table 1. It was observed that the water level measured in the wells was steady on the last reading date.

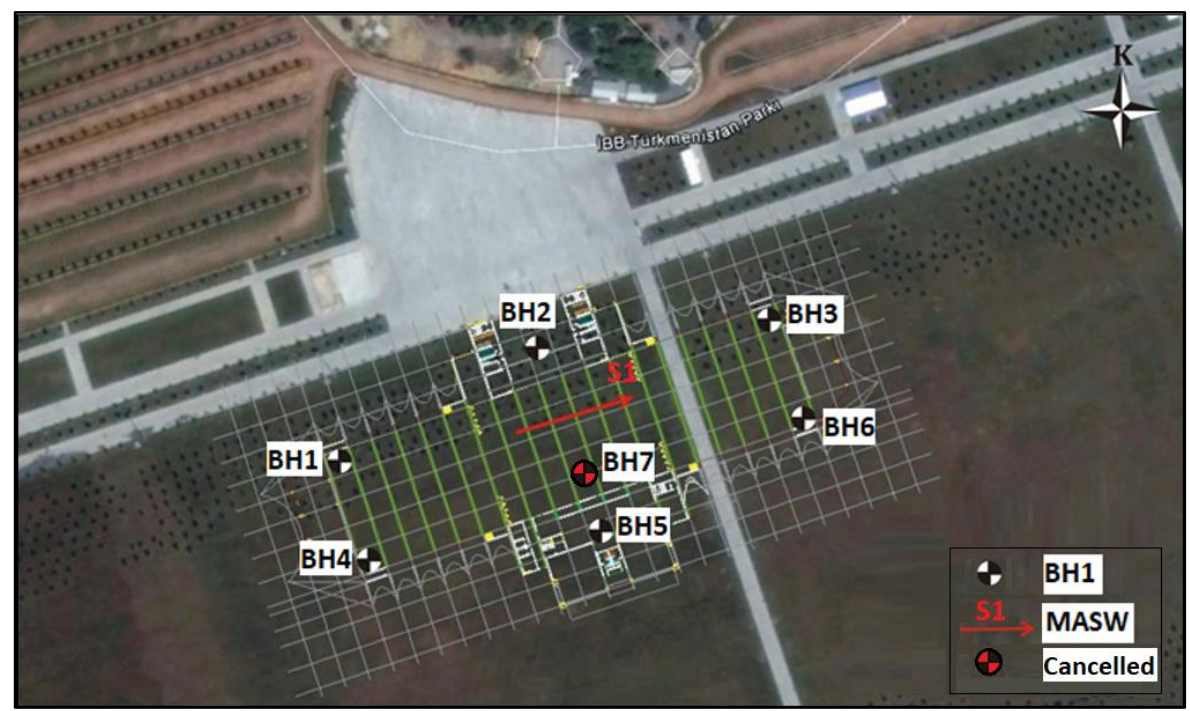

Figure 4. Location map of the study area showing the borehole locations

Table 1. The Ground Water Table (GWT) levels by measurement dates

\begin{tabular}{|c|c|c|c|c|c|c|c|c|c|c|c|c|c|c|c|c|}
\hline 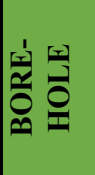 & 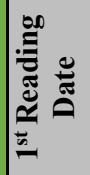 & 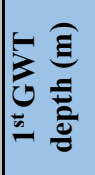 & 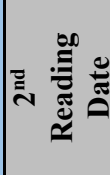 & 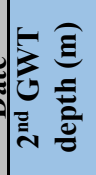 & 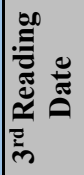 & 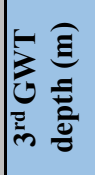 & 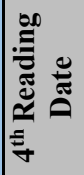 & 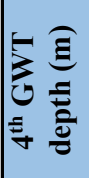 & 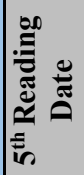 & 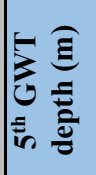 & 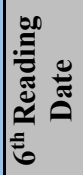 & 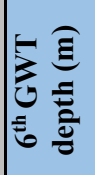 & 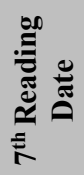 & 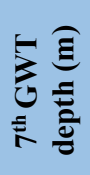 & 竞 & 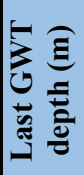 \\
\hline BH1 & $\begin{array}{l}\underset{\Xi}{\Xi} \\
\underset{\infty}{\infty}\end{array}$ & 2.60 & 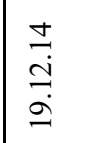 & 2.95 & $\begin{array}{l}\underset{\Xi}{ \pm} \\
\underset{i}{d}\end{array}$ & 3.00 & 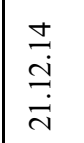 & 3.07 & $\begin{array}{l}\Delta \\
\vec{\sim} \\
\vec{\Delta}\end{array}$ & 3.14 & $\begin{array}{l}\underset{\Xi}{ \pm} \\
\underset{d}{d}\end{array}$ & 3.20 & $\begin{array}{l}\underset{\Xi}{\Xi} \\
\underset{\sim}{\sim}\end{array}$ & 3.20 & $\begin{array}{l} \pm \\
\stackrel{\Xi}{\Xi} \\
\dot{m}\end{array}$ & 3.10 \\
\hline ВH2 & $\begin{array}{l}\underset{J}{ \pm} \\
\stackrel{a}{a}\end{array}$ & 2.96 & 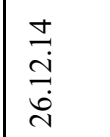 & 3.45 & $\frac{\Delta}{\stackrel{ \pm}{a}}$ & 3.61 & $\begin{array}{l}\underset{J}{ \pm} \\
\underset{\infty}{d}\end{array}$ & 3.68 & $\begin{array}{l}\underset{ \pm}{ \pm} \\
\vec{a}\end{array}$ & 3.75 & $\frac{ \pm}{\stackrel{ \pm}{1}}$ & 3.75 & $\begin{array}{l}\stackrel{ \pm}{ \pm} \\
\stackrel{i}{m}\end{array}$ & 3.80 & $\begin{array}{l}n \\
\stackrel{n}{0} \\
0 \\
0\end{array}$ & 3.75 \\
\hline ВH3 & $\begin{array}{l}\underset{J}{\Delta} \\
\underset{d}{d}\end{array}$ & 3.26 & 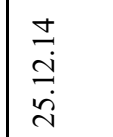 & 3.68 & 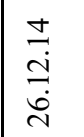 & 3.95 & $\frac{ \pm}{d}$ & 4.00 & $\begin{array}{l}\underset{J}{J} \\
\underset{\infty}{d}\end{array}$ & 4.02 & $\begin{array}{l}\frac{ \pm}{d} \\
\stackrel{d}{d}\end{array}$ & 4.05 & 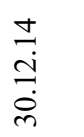 & 4.05 & 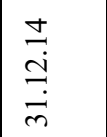 & 4.05 \\
\hline BH4 & 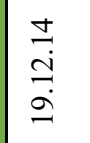 & 2.65 & 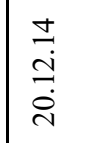 & 3.00 & 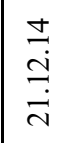 & 3.15 & $\begin{array}{l}\underset{ \pm}{d} \\
\underset{i}{d}\end{array}$ & 3.20 & $\begin{array}{l}\underset{ \pm}{ \pm} \\
\stackrel{d}{d}\end{array}$ & 3.27 & 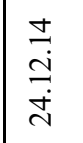 & 3.35 & 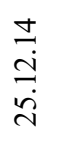 & 3.45 & $\begin{array}{l}\dot{\Xi} \\
\stackrel{\dot{m}}{\leftrightarrows}\end{array}$ & 3.40 \\
\hline BH5 & 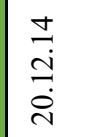 & 4.15 & $\begin{array}{l}\underset{\Xi}{d} \\
\stackrel{\sim}{d}\end{array}$ & 4.73 & 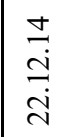 & 5.24 & $\begin{array}{l}\underset{ \pm}{d} \\
\stackrel{d}{d}\end{array}$ & 5.28 & $\begin{array}{l}\dot{J} \\
\stackrel{d}{J} \\
\dot{d}\end{array}$ & 5.30 & $\begin{array}{l}\underset{d}{d} \\
\stackrel{a}{d}\end{array}$ & 5.32 & 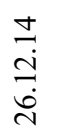 & 5.28 & $\begin{array}{l} \pm \\
\stackrel{\Xi}{ \pm} \\
\dot{m}\end{array}$ & 5.20 \\
\hline BH6 & $\begin{array}{l}\underset{J}{ \pm} \\
\stackrel{i}{d}\end{array}$ & 3.25 & $\begin{array}{l}\underset{\Xi}{J} \\
\underset{\sim}{\Delta}\end{array}$ & 3.84 & $\begin{array}{l}\underset{\sim}{ \pm} \\
\ddot{\sim}\end{array}$ & 4.00 & 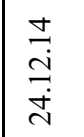 & 4.10 & $\begin{array}{l} \pm \\
\stackrel{\sim}{\sim} \\
\ddot{a}\end{array}$ & 4.15 & 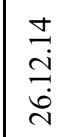 & 4.10 & 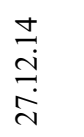 & 4.06 & 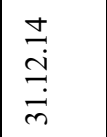 & 4.00 \\
\hline
\end{tabular}

The variation of pressuremeter test results with depth is given in Figure 5. In the soil environment where fill and clay units are deposited throughout the $30 \mathrm{~m}$ borehole depth, the lateral e-ISSN: 2148-2683 deformation characteristics of the layers are varied between 4 to $12 \mathrm{~kg} / \mathrm{cm}^{2}$ in terms of limit pressure, $\mathrm{P}_{\mathrm{L}}$. The variation of the limit pressure with depth exhibits similar trends in all boreholes considered. The variation of the Menard pressuremeter modulus 
with depth, $\mathrm{E}_{\mathrm{M}}$, which is the other measure of the lateral deformation characteristics of the soil layers is given in Figure 6. Although it was observed that the lateral stiffness decreased slightly (ie. $10 \%$ ) in the clay unit between 22 to $30 \mathrm{~m}$ depth, in general, the $E_{M}$ values are observed to reach $230 \mathrm{~kg} / \mathrm{cm}^{2}$ in maximum. This shows that the filling and compaction process is achieved uniformly in the entire area where the thickness of the filling reaches up to $15 \mathrm{~m}$.

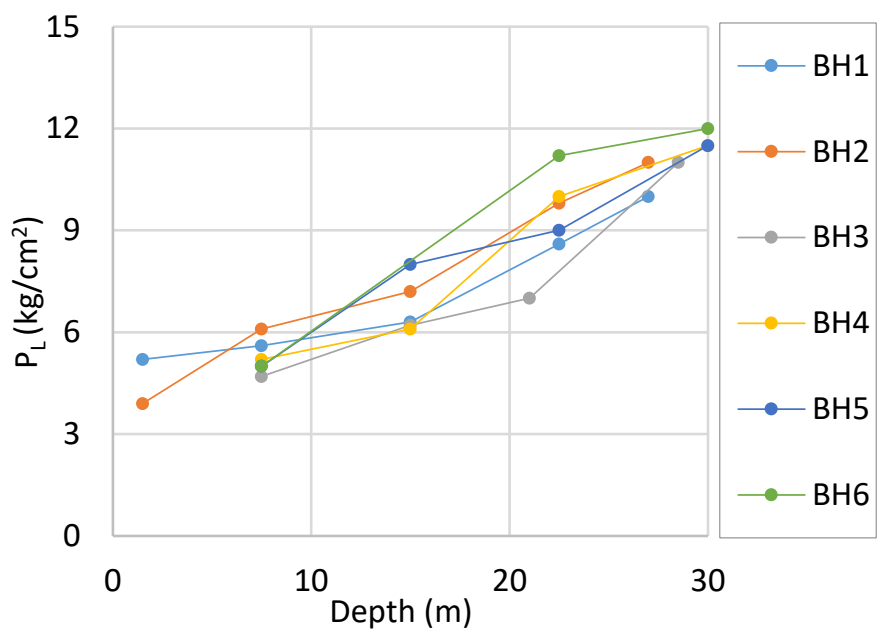

Figure 5 The variation of the limit pressure with depth

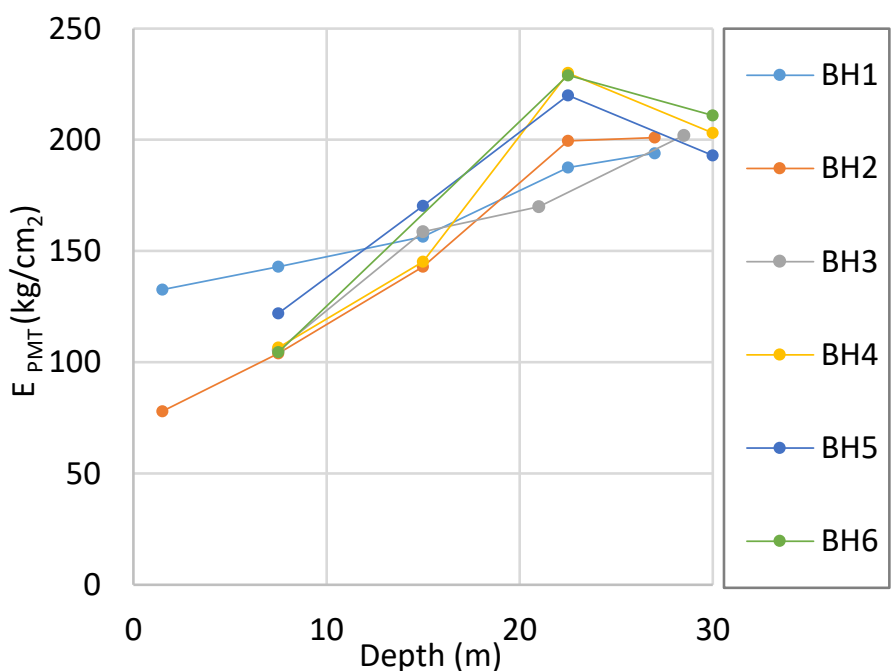

Figure 6 The variation of the pressuremeter modulus with depth

The deformation characteristics of the soil under lateral pressure are measured by the pressuremeter test, while the vertical resistance of the soil to falling rams is measured by the standard penetration test. In both test types, the direction of the applied pressure is different from each other. Therefore, the variation of the lateral stiffness with vertical stiffness is given in Figure 7 in terms of $\mathrm{P}_{\mathrm{L}}$ vs. SPT-N $\mathrm{N}_{60}$ curves. It was observed that the SPT-N 60 value, measured with increasing depth, reached the maximum value at the final depth which was $30 \mathrm{~m}$. It is seen that the consolidation rate of clay units observed at this level is quite high. However, it is concluded that the lateral stiffness decreased for the soil layers above $30 \mathrm{~m}$ depth, especially for the boreholes drilled on the north of the study area (ie. BH4, BH5, BH6). There is an increase in the limit pressure value in all soil layers encountered along with the depth of boreholes. The maximum limit pressure is measured by BH6 at $30 \mathrm{~m}$ depth as $12 \mathrm{~kg} / \mathrm{cm}^{2}$ while it was only 5 $\mathrm{kg} / \mathrm{cm}^{2}$ at $8 \mathrm{~m}$ depth from ground surface ant the SPT-N 60 is measured as 40 for the considered layer (Figure 8).

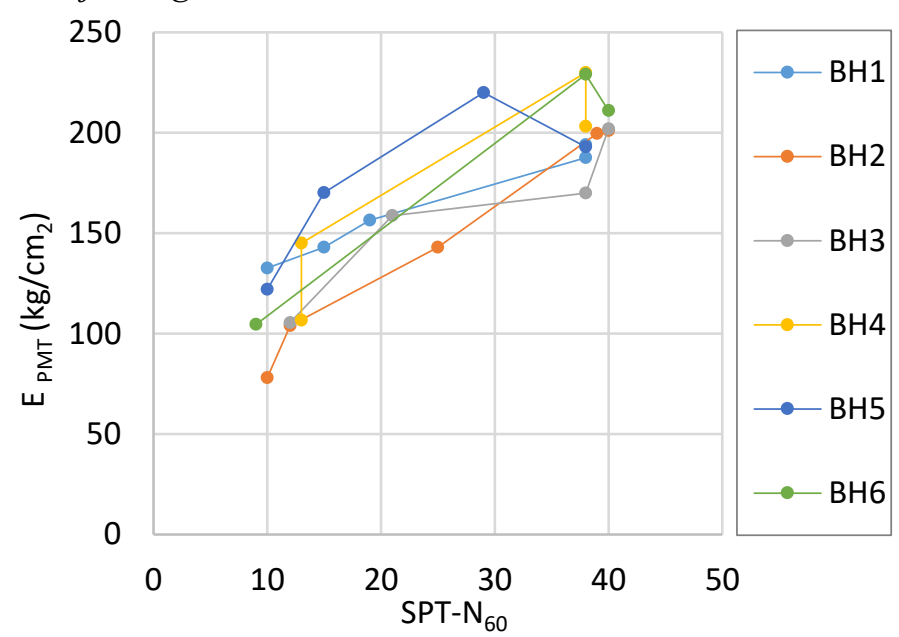

Figure 7 The variation of the pressuremeter modulus with SPT$\mathrm{N}_{60}$ value

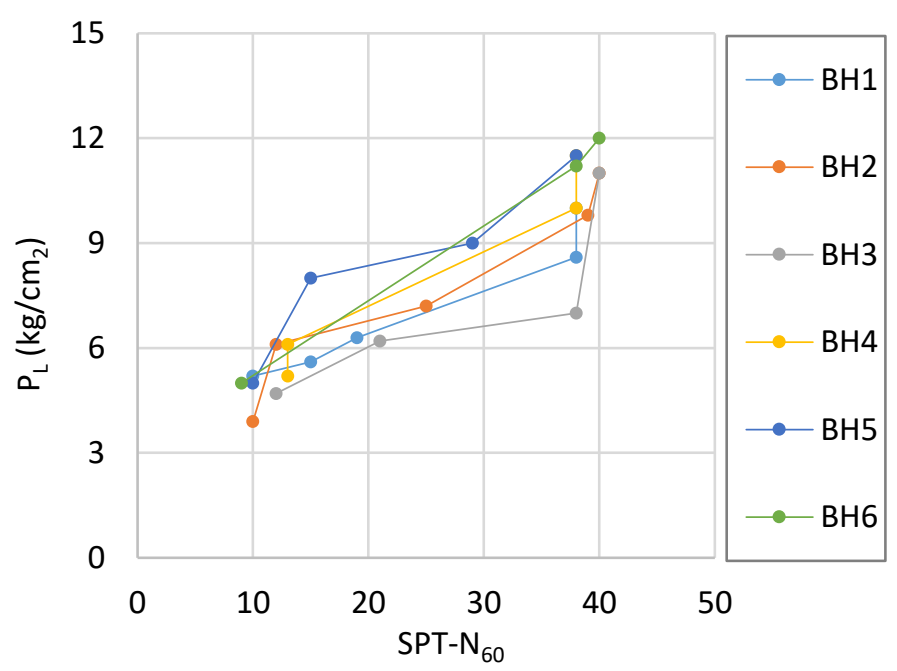

Figure 8 The variation of the limit pressure with SPT-N 60 value

The correlations obtained by the researchers are summarized in Table 2. In this study, the relationship between limit pressure $\mathrm{P}_{\mathrm{L}}$ and SPT- $\mathrm{N}_{60}$ was obtained as follows;

$\mathrm{P}_{\mathrm{L}}=0.1865 \mathrm{~N}_{60}+3.1256$

The relationship between pressuremeter modulus $\mathrm{E}_{\mathrm{M}}$ and $\mathrm{SPT}-\mathrm{N}_{60}$ is formulated as below;

$\mathrm{E}_{\mathrm{M}}=3.0789 \mathrm{~N}_{60}+85.818$

Considering all of the tests performed, it is more meaningful to draw conclusions in terms of the relationships examined. A very high correlation coefficient (ie. $\mathrm{R}^{2}: 0.83$ ) was found between limit pressure $\mathrm{P}_{\mathrm{L}}$ and SPT-N 60 (Figure 9). Although this relationship has been demonstrated by many researchers on natural soils, it is noteworthy that similar results are obtained in an artificially filled soil environment. As another deformation measure, the relationship between $\mathrm{E}_{\mathrm{M}}$ and $\mathrm{SPT}-\mathrm{N}_{60}$ was examined, and similar results were obtained. The correlation coefficient between these two parameters was calculated as $\mathrm{R}^{2}$ : 0.78 (Figure 10).

Briaud and Jordan [8] proposed an equation to calculate the bearing capacity of a soil layer using pressuremeter parameters as;

$\mathrm{q}_{\mathrm{u}}=\mathrm{k} \cdot \mathrm{P}_{\mathrm{L}}+\mathrm{q}_{\mathrm{o}}$

where $\mathrm{k}$ is the pressuremeter bearing capacity factor determined using the chart (Figure 11), $\mathrm{q}_{\mathrm{o}}$ is the total stress overburden 
European Journal of Science and Technology

pressure, $\mathrm{P}_{\mathrm{L}}$ is the limit pressure measured by the pressuremeter test. The variation of the calculated ultimate bearing capacity of the soil layers with depth is represented in Figure 12. The bearing capacity increases as the depth of the soil layer increases. The highest ultimate bearing capacity, $\mathrm{q}_{\mathrm{u}}$ was obtained by BH6 as 10.3 $\mathrm{kg} / \mathrm{cm}^{2}$. The general trend of the calculated values along the soil profile proves that the artificially filled upper soil layers (i.e. between 0 to $15 \mathrm{~m}$ from grund surface) represent similar bearing capacity values which indicate that the filling and compaction processes are carried out with the same care in all portions of the filling area. A slightly higher bearing capacity value are achieved in submarine deposits which are located deeper than the fill layer.

Table 2 Correlations developed by literature studies

\begin{tabular}{|c|c|c|}
\hline Equation & Soil type & Reference \\
\hline $\mathrm{E}_{\mathrm{m}}(\mathrm{KPa})=388.67 \mathrm{~N}_{60}+4554$ & Sandy silty clay & Yagiz et al. [10] \\
\hline $\mathrm{E}_{\mathrm{m}}(\mathrm{MPa})=1.61 N_{60}^{0.71}$ & Clay & Bozbey and Togrol [11] \\
\hline $\mathrm{E}_{\mathrm{m}}(\mathrm{MPa})=1.33 N_{60}^{0.77}$ & Sand & Bozbey and Togrol [11] \\
\hline $\mathrm{E}_{\mathrm{m}}(\mathrm{MPa})=0.2885 N_{60}^{1.4}$ & Clay & Kayabasi [14] \\
\hline $\mathrm{E}_{\mathrm{m}}(\mathrm{MPa})=1.24 N_{60}^{0.94}-11.04 \operatorname{Ln} \omega+37.9$ & Clay & Kayabasi [14] \\
\hline $\mathrm{E}_{\mathrm{m}}(\mathrm{MPa})=0.68 P I+0.0104 N_{60}^{2.067}-10.44 L n \omega+23.82$ & Clay & Kayabasi [14] \\
\hline $\begin{array}{l}\mathrm{E}_{\mathrm{m}}(\mathrm{MPa})=37.83-0.0086 \omega-29.5 \mathrm{Ln} \mathrm{N}_{60^{-}} \\
0.0034 \omega^{2}+8.55\left(\operatorname{Ln} \cdot \mathrm{N}_{60}\right)^{2}-0.018 \omega \operatorname{LnN}_{60}\end{array}$ & & Moayed et al. [19] \\
\hline $\mathrm{E}_{\mathrm{m}} / \mathrm{P}_{\mathrm{a}}=9.8 \mathrm{~N}_{60}-94.3$ & Silty sand & Cheshomi and Ghodrati [13] \\
\hline $\mathrm{E}_{\mathrm{m}} / \mathrm{P}_{\mathrm{a}}=10 \mathrm{~N}_{60}-26.7$ & Silty clay & Cheshomi and Ghodrati [13] \\
\hline $\mathrm{E}_{\mathrm{m}}(\mathrm{MPa})=0.5187 \mathrm{~N}_{60}+3.3673$ & Sand & Yildiz [12] \\
\hline $\mathrm{E}_{\mathrm{m}}(\mathrm{MPa})=0.4121 \mathrm{~N}_{60}+6.1614$ & Clay & Yildiz [12] \\
\hline $\mathrm{P}_{\mathrm{L}}(\mathrm{KPa})=29.45 \mathrm{~N}_{60}+219.7$ & Sandy silty clay & Yagiz et al.[10] \\
\hline $\mathrm{P}_{\mathrm{L}}(\mathrm{MPa})=0.26 N_{60}^{0.57}$ & Clay & Bozbey and Togrol [11] \\
\hline $\mathrm{P}_{\mathrm{L}}(\mathrm{MPa})=0.33 N_{60}^{0.51}$ & Sand & Bozbey and Togrol [11] \\
\hline $\mathrm{P}_{\mathrm{L}}(\mathrm{MPa})=0.0425 N_{60}^{1.965}$ & Clay & Kayabasi [14] \\
\hline $\mathrm{P}_{\mathrm{L}}(\mathrm{MPa})=0.03 N_{60}^{1.26}+108.4 \omega^{-1.69}$ & Clay & Kayabasi [14] \\
\hline $\mathrm{P}_{\mathrm{L}}(\mathrm{MPa})=0.03 N_{60}^{1.26}+108.4 \omega^{-0.011}-58.76$ & Clay & Kayabasi [14] \\
\hline $\mathrm{P}_{\mathrm{L}} / \mathrm{P}_{\mathrm{a}} \quad=\mathrm{N}_{60}-20.8$ & Silty sand & Cheshomi and Ghodrati [13] \\
\hline $\mathrm{P}_{\mathrm{L}} / \mathrm{P}_{\mathrm{a}}=0.5 \mathrm{~N}_{60}+42$ & Silty sand & Cheshomi and Ghodrati [13] \\
\hline $\begin{array}{l}\mathrm{P}_{\mathrm{L}}(\mathrm{MPa})=3.336-0.0638 \mathrm{PI} 2.405 . \mathrm{LnN}_{60}+0.00665 \mathrm{PI}^{2} \\
+1.582\left(\mathrm{Ln} \cdot \mathrm{N}_{60}\right)^{2}-0.1403 \mathrm{PILn} . \mathrm{N}_{60}\end{array}$ & & Moayed et al. [19] \\
\hline $\mathrm{P}_{\mathrm{L}}(\mathrm{MPa})=0.0265 \mathrm{~N}_{60}+1.1745$ & Sand & Yildiz [12] \\
\hline $\mathrm{P}_{\mathrm{L}}(\mathrm{MPa})=0.0329 \mathrm{~N}_{60}+0.7978$ & Clay & Yildiz [12] \\
\hline
\end{tabular}




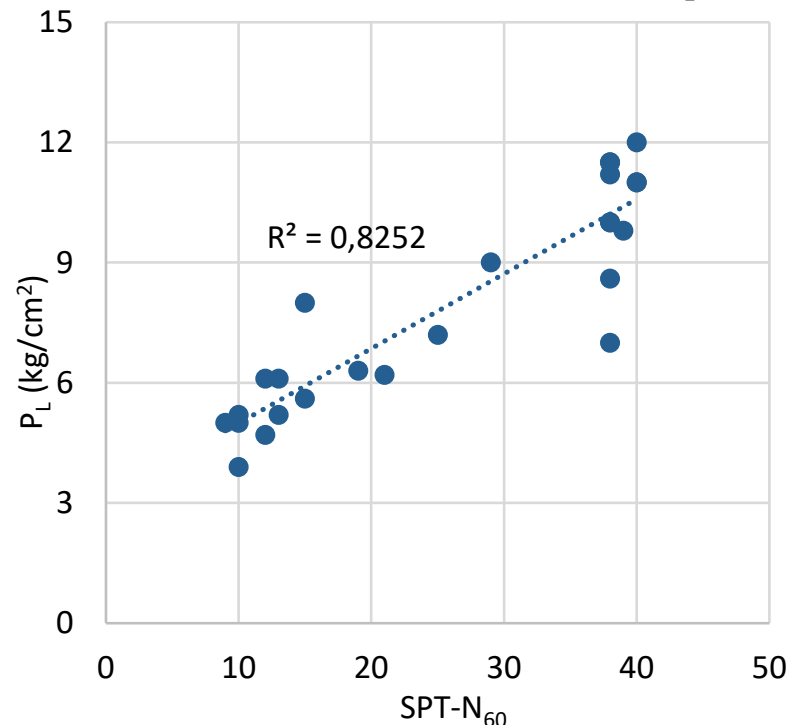

Figure 9 The variation of $\mathrm{P}_{\mathrm{L}}$ with $\mathrm{SPT}-\mathrm{N}_{60}$

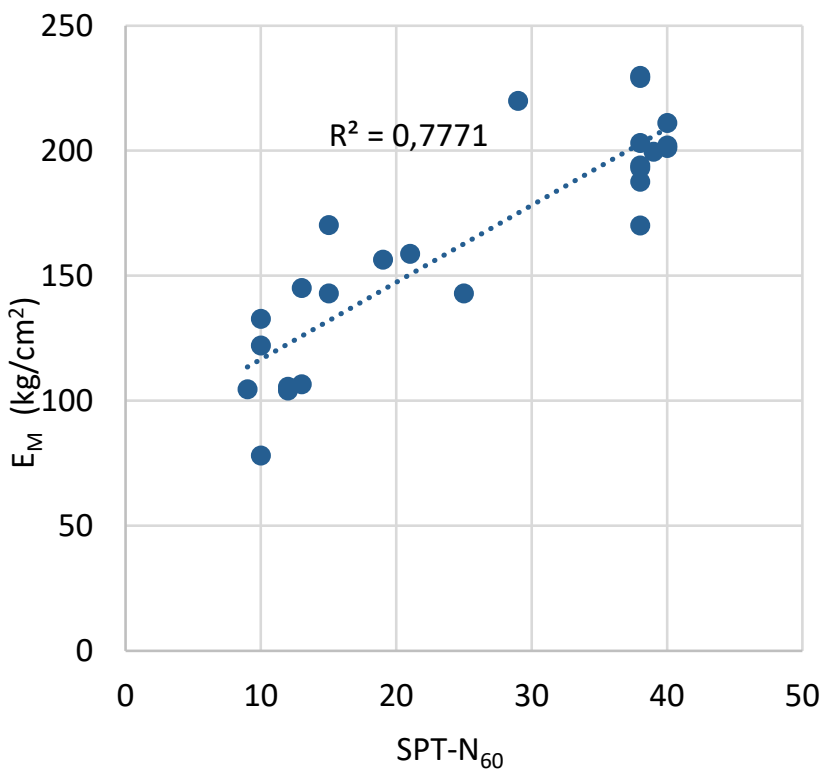

Figure 10 The variation of $\mathrm{E}_{\mathrm{M}}$ with $\mathrm{SPT}-\mathrm{N}_{60}$

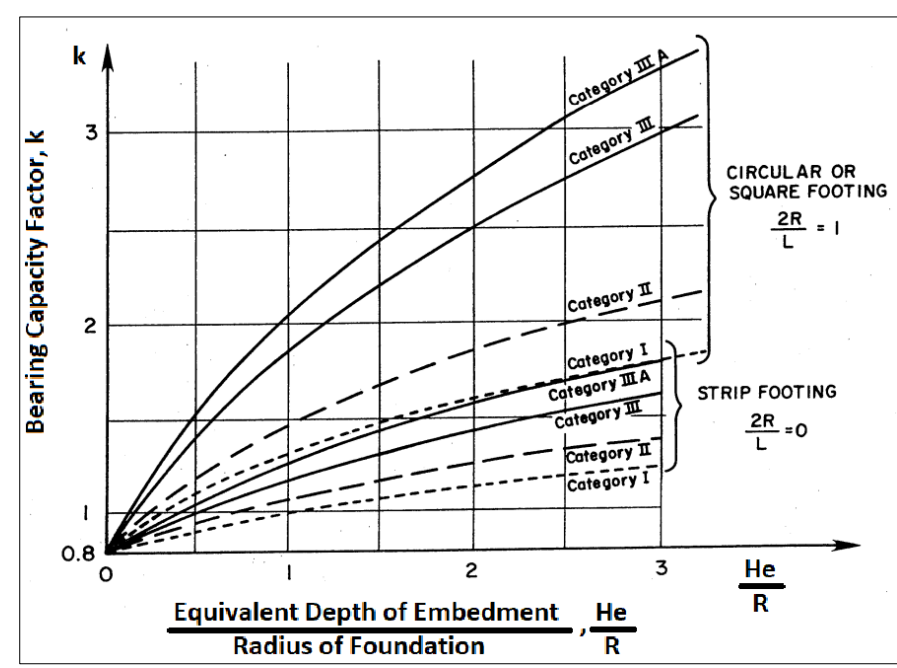

Figure 11. Bearing capacity factor chart [20]

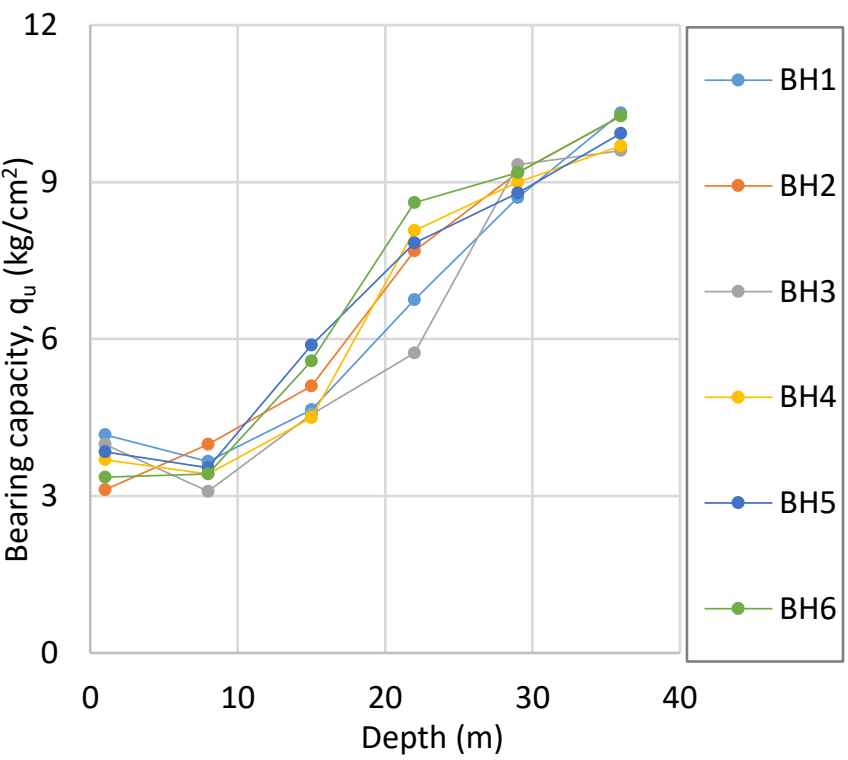

Figure 12 The variation of calculated bearing capacity with depth

Table 3. Soil categories for use of bearing capcity chart

\begin{tabular}{|c|c|c|}
\hline $\begin{array}{c}\text { Limit } \\
\text { Pressure, } \\
\left(\mathrm{kN} / \mathbf{m}^{2}\right)\end{array}$ & Soil Type & Category \\
\hline 718 & Soft Clay & 1 \\
\hline 861 & Silt and Soft Chalk & 1 \\
\hline 718 & $\begin{array}{c}\text { Loose Clayey, Silty, or Muddy } \\
\text { Soil }\end{array}$ & 2 \\
\hline $1-2010$ & Medium Dense Sand and Gravel & 2 \\
\hline $1.2-3016$ & Clay and Compact Silt & 2 \\
\hline $1.5-4022$ & Marl and Limestone-Marl & 2 \\
\hline $1-2490$ & Weathered Chalk & 2 \\
\hline $2.5-4022$ & Weathered Rock & 2 \\
\hline 3017 & Fragmented Chalk & 2 \\
\hline 4501 & Very Compact Marl & 2 \\
\hline 2490 & $\begin{array}{c}\text { Dense to Very Dense Sand and } \\
\text { Gravel Fragmented Rock }\end{array}$ & 3 \\
\hline 4501 & $\begin{array}{c}\text { Dense to Very Dense Sand and } \\
\text { Gravel Fragmented Rock }\end{array}$ & 3 \\
\hline
\end{tabular}

\section{Conclusion}

The variability of the geotechnical parameters depending on the nonlinear nature of the soil challenges the designers, especially during the preliminary design phase. Site conditions, economic and technical constraints encountered in some cases necessitate alternative approaches to obtain the design parameters. In this study, the correlation between parameters, which is frequently performed for natural soils, was made for the 
first time for an artificially filled area. In this context, the variation of the parameters obtained with the site investigation study carried out in the area with a total surface area of $75.000 \mathrm{~m}^{2}$ was examined, and correlation relations between the parameters were developed. The findings obtained as a result of the study are as follows;

$>$ The drilling works carried out in the study area show that the filling works create uniform soil conditions throughout the area.

$>$ Horizontal and vertical stiffness values obtained as a result of pressuremeter and standard penetration tests are increasing inconsistency with depth.

$>$ The bearing capacity values obtained from pressuremeter tests increase consistently with increasing depth.

$>$ The correlation coefficients obtained between pressuremeter test results and SPT-N blow number are satisfactorily high and can be used for preliminary design of superstructures will be built on it.

$>$ In addition to the field investigation studies, these correlational relationships give important information about the strength of the soil under possible superstructure loads to be built on the area.

\section{Acknowledgement}

The author would like to thank Istanbul Metropolitan Municipality for sharing the data used in the study.

\section{References}

[1] Özkan,Ö., Alp, J \& Tanrıverdi, Ç. (2015). Dolgu Alanları : Kıyı Sınırını Yeniden Oluşturmak. 9. Uluslararası Sinan Sempozyumu, 21-22 Nisan, 2015.

[2] https://cevreatlasi.org/case/yenikapi-dolgu alani/\#14.5/40.99711/28.95081

[3] Çinicioğlu, S. F., \& Toğrol, E., Embankment Design on Soft Clays, American Society of Civil Engineers Journal of Geotechnical Engineering, Vol 117, 1991.

[4] Akbay, Z.A, \& Çinicioğlu, S.F.. (2016). Dolgu Zemin Etkileşiminde Malzeme Modeli Etkisi, Çukurova Üniversitesi Mühendislik Mimarlık Fakültesi Dergisi, Vol 31, 35-50, 2016.

[5] Jay, A., Sivakugan, N., \& Das, B.M. (2016). Correlations of Soil and Rock Properties in Geotechnical Engineering, DOI 10.1007/978-81- 322-2629-1.

[6] Chiang, Y. \& Ho, Y. (1980). Pressuremeter method for foundation in Hongkong. In Proceedings of the Sixth Southeast Asian Conference on Soil Engineering, Taipei, Taiwan, pp. 31-42.

[7] Ohya, S., Imai, T., \& Matsubara, M. (1982). Relation between $\mathrm{N}$ value by SPT and LLT pressuremeter results. Proceeding 2nd European Symposium on Penetration Testing, Amsterdam, 1: 125-130.

[8] Briaud, J.L., \& Jordan,G. (1983). The Pressuremeter and the Design of Highway Related Foundations Research Study 2-5-83-340, Texas Transportation Institute The Texas A\&M University System College Station Report, Texas.

[9] Briaud, J.L. (1992). The Pressuremeter. A.A. Balkema, Rotterdam.

[10] Yagiz, S., Akyol, E., \& Sen, G. (2008). Relationship between the standard penetration test and the pressuremeter test on sandy silty clays: A case study from Denizli. Bulletin of Engineering Geology and the Environment, 67(3): 405-410.

[11] Bozbey, I., \& Togrol, E. (2010). Correlation of standard penetration test and pressuremeter data: A case study from Istanbul, Turkey. Bulletin of Engineering Geology and the Environment, 69(4), 505-515. https://doi.org/10.1007/s10064-009-0248-4

[12] Yild1z, Ö. (2021). Correlation Between Spt and Pmt Results for Sandy and Clayey Soils. Eskişehir Technical University Journal of Science and Technology A Applied Sciences and Engineering, 22(2), 175-188. https://doi.org/10.18038/estubtda.896491

[13] Cheshomi, A., \& Ghodrati, M. (2014). Estimating Menard pressuremeter modulus and limit pressure from SPT in silty sand and silty clay soils. A case study in Mashhad, Iran Int. J. Geomech. Geoeng.10(3): 194-202.

[14] Kayabasi, A. (2012). Prediction of pressuremeter modulus and limit pressure of clayey soils by simple and nonlinear multiple regression techniques: A case study from Mersin, Turkey. Environmental Earth Sciences. 66(8): 2171-2183.

[15] Aladag, C.H., Kayabasi, A., \& Gokceoglu, C. (2013). Estimation of pressuremeter modulus and limit pressure of clayey soils by various artificial neural network models. Neural Computing and Applications, 23(2): 333-339.

[16] Agan, C. (2013). Silt Biriminde (Kastamonu, Türkiye) Yapılan Menard Presiyometre, Standart Penetrasyon ve Laboratuvar Deney Sonuçları Arasındaki İlişkilerin Araştırılması. Teknik Dergi. 6679-6698.

[17] Narimani, S., Chakeri H., \& Davarpanah, S.M. (2018). Simple and Non-Linear Regression Techniques Used in Sandy-Clayey Soils to Predict the Pressuremeter Modulus and Limit Pressure: A Case Study of Tabriz Subway. Periodica Polytechnica Civil Engineering. 62(3): 825-839.

[18] Kavur, B., Dodigovic, F., Jug, J., \& Strelec, S. (2019). The Interpretation of CPTu, PMT, SPT and Cross-Hole Tests in Stiff Clay. IOP Conference Series: Earth and Environmental Science. 221(1).

[19] Moayed, R., Kordnaeij, A., \& Mola-Abasi, H. (2018). Pressuremeter Modulus and Limit Pressure of Clayey Soils Using GMDH-Type Neural Network and Genetic Algorithms. Geotechnical and Geological Engineering, 36(1), 165-178. https://doi.org/10.1007/s10706-017$\underline{0314-9}$

[20] Menard.,L (1975). The Menard pressuremeter: Interpretation and application of pressuremeter test results to foundation design. General Memorandum. 